\title{
Effect of Sucrose Concentration on Shoot Proliferation of Papaya (Carica papaya L.)
}

\author{
Neeharika Kanth", Anil K. Singh and M.M. Syamal \\ Department of Horticulture, Institute of Agricultural Sciences, Banaras Hindu University, \\ Varanasi-221 005, (U.P.), India \\ *Corresponding author
}

\section{A B S T R A C T}

\begin{tabular}{|l|}
\hline Ke y w or d s \\
Sucrose, Shoot tip, \\
Axillary bud, Shoot \\
proliferation, \\
Culture response. \\
\hline Article Info \\
\hline $\begin{array}{l}\text { Accepted: } \\
\text { 14 September } 2017 \\
\text { Available Online: } \\
\text { 10 October } 2017\end{array}$ \\
\hline
\end{tabular}

An experiment was conducted to study the effect of sucrose concentration in MS basal media on shoot proliferation of papaya using shoot tip and axillary bud as explant. The experiment was conducted in Completely Randomized Design with eleven treatments and three replications. The aim of the experiment was to study the effect of media sucrose concentration on shoot proliferation while using shoot tip and axillary bud as explant. The different parameters taken for study were number of shoots per explant, length of shoot (cm) and culture response (\%). Maximum number of shoots, maximum shoot length, maximum culture response $(\%)$ was observed in media having $30 \mathrm{~g} / 1$ sucrose while culturing both the explants. Minimum number of shoots per explants, minimum shoot length, minimum culture response was noticed in media with $10 \mathrm{~g} / \mathrm{l}$ sucrose in both shoot tip and axillary bud explants. The different parameters under study exhibited an increasing trend when the sucrose concentration increased from $10 \mathrm{~g} / \mathrm{l}$ to $30 \mathrm{~g} / \mathrm{l}$ but showed a decreasing trend in parameters under study when sucrose concentration was increased further. The most suitable sucrose concentration for shoot proliferation was found to be $30 \mathrm{~g} / \mathrm{l}$.

\section{Introduction}

Papaya is an important fruit crop of tropical and subtropical regions of the world. Scientifically, it is named Carica papaya L. It belongs to family Caricaceae. It is the only edible species of this genus. This family includes six genera. The papaya is believed to be native to southern Mexico and neighbouring Central America. It is currently cultivated in Florida, Hawaii, Eastern British Africa, South Africa, Sri Lanka, India, Canary Islands, Malaysia and Australia. It is now present in every tropical and subtropical country. India, Brazil, Indonesia, Nigeria, and Mexico are the world's biggest producers of papaya. India is the leading papaya producing country in the world. Papayas, which are high in vitamins $\mathrm{A}$ and $\mathrm{C}$ and calcium, are often used fresh in fruit salads and desserts, as well as prepared in juices and jams or dried. Some South East Asian dishes call for the unripe fruits to be cooked and used as vegetables. Papayas produce an enzyme, papain, which aids in digestion. The fruits can be consumed as fruit when mature and as vegetable when immature. Oral consumption of Carica papaya L. extract leaves is found to increase the platelet levels as early as 24 hours with a significant 
increase in the total white blood cell and neutrophil counts as well (Subenthiran et al., 2013).

Micropropagation systems are heterotrophic and the main source of organic carbon for plant growth and development is absorbed as sucrose from the media (George et al., 2008). Sucrose acts during plant tissue culture as a fuel source for sustaining photomixotrophic metabolism, ensuring optimal development, although other important roles such as carbon precursor or signaling metabolite have more recently been highlighted by (Coupe et al., 2006; Fila et al., 2006; Muller et al., 2011). Sucrose also supports the maintenance of osmotic potential and the conservation of water in cells. So, study was conducted to figure out the effect of different concentration of sucrose on shoot proliferation.

\section{Materials and Methods}

The experiment was conducted in Tissue culture laboratory, Department of Horticulture, Institute of Agricultural Sciences, Banaras Hindu University, Varanasi (U.P.), India. Murashige and Skoog media (Murashige and Skoog, 1962) was taken as basal media for all studies. The four stock solutions each of Macronutrients, micronutrients, Fe-EDTA and vitamins were prepared in advance. For preparing stock solutions I, II, III and IV appropriate amount of each chemicals were taken in volumetric flasks after dissolving them separately in a beaker with double distilled water and then the final volume was made up by adding double distilled water. Stock III was prepared by weighing $\mathrm{FeSO}_{4} 7 \mathrm{H}_{2} \mathrm{O}$ and sodium salt of EDTA. $2 \mathrm{H}_{2} \mathrm{O}$ separately in the required quantities, dissolved by slight warming, and then mixed thoroughly, $\mathrm{pH}$ was adjusted to 5.5. MS media was prepared by taking required amount of each of these stock solutions and final volume was made up to 1litre by double distilled water. The different levels of $\mathrm{pH}$ of media was made by adjusting with either $0.1 \mathrm{~N} \mathrm{HCl}$ or $0.1 \mathrm{~N} \mathrm{NaOH}$. The different parameters studied were number of shoots per explant, length of shoot $(\mathrm{cm})$ and culture response (\%). The number of shoots per plant were counted at different growth stages of plant in each treatment and was recorded. The length of proliferated shoots were measured in $(\mathrm{cm})$ and average was worked out for each explant. The culture response on sprouting of buds from explants in each treatment was recorded by dividing total number of cultures responding for sprouting and total number of cultures inoculated and calculated in percentage. The experiment was conducted in Completely Randomised Design (Panse and Sukhatme, 1967).

\section{Results and Discussion}

Table 1 depicts the data recorded with effect of different concentration of sucrose in media with shoot tip as explant on number of shoots per explant and length of shoot $(\mathrm{cm})$ and culture response (\%). The data were statistically analysed and the interpretation of data are as follows. The data of effect of different levels of sucrose in media on number of shoots produced show that all the treatments gave a significant effect on number of shoots produced. Maximum number of shoots (12.16) was found in $30 \mathrm{~g} / \mathrm{l}$ sucrose which was followed by $25 \mathrm{~g} / 1$ sucrose concentration. Minimum number of shoots per explant (4.00) was produced in case of 10 $\mathrm{g} / \mathrm{l}$ sucrose. All the treatments exerted a significant effect on shoot length produced by the effect of different concentrations of sucrose. Maximum shoot length $(4.56 \mathrm{~cm})$ was observed in case of $30 \mathrm{~g} / \mathrm{l}$ sucrose which was followed by $15 \mathrm{~g} / 1$ sucrose. Minimum shoot length $(0.82 \mathrm{~cm})$ was noticed with $10 \mathrm{~g} / \mathrm{l}$ sucrose. All the treatments caused significant effect on culture response. Maximum culture response $(85.50 \%)$ was seen in $30 \mathrm{~g} / \mathrm{l}$ sucrose which was followed by $25 \mathrm{~g} / \mathrm{l}$ sucrose. While, 
minimum (20.33\%) was seen in $10 \mathrm{~g} / \mathrm{l}$ sucrose. No response $(0.00)$ was seen in Control in case of every parameter under study.

When axillary bud was taken as explant, as depicted in Table 2, all the treatments gave a significant effect on number of shoots produced. Maximum number of shoots (11.33) was found in $30 \mathrm{~g} / \mathrm{l}$ sucrose which was statistically at par with $25 \mathrm{~g} / \mathrm{l}$ sucrose. Minimum number of shoots per explants (3.63) was produced in case of $10 \mathrm{~g} / 1$ sucrose which was statistically at par with $55 \mathrm{~g} / \mathrm{l}$ sucrose (3.83). All the treatments exerted a significant effect on shoot length produced by the effect of different concentrations of sucrose. Maximum shoot length $(3.51 \mathrm{~cm})$ was observed in case of $30 \mathrm{~g} / 1$ sucrose which was statistically at par with $35 \mathrm{~g} / \mathrm{l}$ sucrose. Minimum shoot length $(0.56 \mathrm{~cm})$ was noticed in $10 \mathrm{~g} / \mathrm{l}$ sucrose. The data clearly indicated that the treatments caused significant effect on culture response. Maximum culture response $(75.66 \%)$ was seen in $30 \mathrm{~g} / \mathrm{l}$ sucrose. While, minimum $(11.41 \%)$ was seen in $10 \mathrm{~g} / \mathrm{l}$ sucrose. No response $(0.00 \%)$ was seen in Control in all the parameters studied.

Table.1 Effect of sucrose concentration on shoot proliferation of papaya using shoot tip explant

\begin{tabular}{|l|l|l|l|l|}
\hline Treatments & Sucrose $(\mathbf{g} / \mathbf{l})$ & $\begin{array}{l}\text { Number of shoots } \\
\text { per explant }\end{array}$ & $\begin{array}{l}\text { Length of shoot } \\
(\mathbf{c m})\end{array}$ & $\begin{array}{l}\text { Culture response } \\
(\mathbf{\%})\end{array}$ \\
\hline $\mathrm{T}_{1}$ & 0 & 0.00 & 0.00 & 0.00 \\
\hline $\mathrm{T}_{2}$ & 10 & 4.00 & 0.82 & 20.33 \\
\hline $\mathrm{T}_{3}$ & 15 & 6.66 & 1.08 & 30.66 \\
\hline $\mathrm{T}_{4}$ & 20 & 7.50 & 1.54 & 50.50 \\
\hline $\mathrm{T}_{5}$ & 25 & 9.00 & 2.27 & 60.50 \\
\hline $\mathrm{T}_{6}$ & 30 & 12.16 & 4.56 & 85.50 \\
\hline $\mathrm{T}_{7}$ & 35 & 8.00 & 3.56 & 75.50 \\
\hline $\mathrm{T}_{8}$ & 40 & 7.33 & 3.38 & 70.83 \\
\hline $\mathrm{T}_{9}$ & 45 & 6.33 & 2.82 & 66.16 \\
\hline $\mathrm{T}_{10}$ & 50 & 5.00 & 2.56 & 55.16 \\
\hline $\mathrm{T}_{11}$ & 55 & 4.50 & 1.96 & 52.66 \\
\hline SEm \pm & & 0.42 & 0.06 & 0.49 \\
\hline C.D. at $5 \%$ & & 1.23 & 0.20 & 1.44 \\
\hline
\end{tabular}

Table.2 Effect of sucrose concentration on shoot proliferation of papaya using axillary bud explant

\begin{tabular}{|l|l|l|l|l|}
\hline Treatments & Sucrose $\mathbf{( g / l )}$ & $\begin{array}{l}\text { Number of shoots } \\
\text { per explants }\end{array}$ & $\begin{array}{l}\text { Length of shoot } \\
(\mathbf{c m})\end{array}$ & $\begin{array}{l}\text { Culture response } \\
(\boldsymbol{\%})\end{array}$ \\
\hline $\mathrm{T}_{1}$ & 0 & 0.00 & 0.00 & 0.00 \\
\hline $\mathrm{T}_{2}$ & 10 & 3.63 & 0.56 & 11.41 \\
\hline $\mathrm{T}_{3}$ & 15 & 5.50 & 0.76 & 20.50 \\
\hline $\mathrm{T}_{4}$ & 20 & 6.00 & 1.27 & 50.66 \\
\hline $\mathrm{T}_{5}$ & 25 & 8.00 & 1.52 & 60.83 \\
\hline $\mathrm{T}_{6}$ & 30 & 11.33 & 3.51 & 75.66 \\
\hline $\mathrm{T}_{7}$ & 35 & 7.66 & 2.52 & 70.66 \\
\hline $\mathrm{T}_{8}$ & 40 & 6.33 & 2.17 & 60.66 \\
\hline $\mathrm{T}_{9}$ & 45 & 5.80 & 1.55 & 55.33 \\
\hline $\mathrm{T}_{10}$ & 50 & 4.00 & 1.26 & 50.66 \\
\hline $\mathrm{T}_{11}$ & 55 & 3.83 & 1.07 & 45.16 \\
\hline SEm \pm & & 0.51 & 0.08 & 0.74 \\
\cline { 3 - 5 } C.D. at 5\% & & 1.50 & 0.25 & 2.17 \\
\hline
\end{tabular}


The above findings are in agreement with the findings of Patel et al., 2013; Kabir et al., 2007; Heringer et al., 2013; Tetsushi et al., 2008.

Maximum number of shoots, maximum shoot length, maximum culture response (\%) was observed in media having $30 \mathrm{~g} / 1$ sucrose while culturing both the explants. Minimum number of shoots per explants, minimum shoot length, minimum culture response was noticed in media with $10 \mathrm{~g} / \mathrm{l}$ sucrose in both shoot tip and axillary bud explants. The different parameters under study exhibited an increasing trend when the sucrose concentration increased from $10 \mathrm{~g} / \mathrm{l}$ to $30 \mathrm{~g} / \mathrm{l}$ but showed a decreasing trend in parameters under study when sucrose concentration was increased further. High sucrose concentration in the media restricts the photosynthetic efficiency of cultured plants by reducing the levels of chlorophyll, key enzymes for photosynthesis and epicuticular waxes promoting the formation of structurally and physiologically abnormal stomata. High sucrose often employed for raising cultures conditions seems to restrict photosynthetic efficiency of leafy shoots.

Although such plantlets may appear normal, they are unlikely to be actively photosynthesizing. This is because of the exogenous supply of sucrose, which does not necessitate the normal development of photosynthetic apparatus. Further increase of sucrose to $6 \%$ induces browning of media which is detrimental for growth of the shoots.

Therefore, understanding the physiology of plant cultured in - vitro and the changes they undergo during the process should facilitate the development of a successful protocol (Hazarika, 2006). For in- vitro growth, a continuous supply of exogenous sucrose is required (2-3\%) as a carbon source (Hazarika et al., 2000, 2004, 2003a, 2003b).
On the basis of above findings, it can be concluded that for in vitro shoot proliferation of papaya, $30 \mathrm{~g} / \mathrm{l}$ sucrose concentration is optimum for number of shoots, shoot length and culture response.

\section{Abbreviations used}

MS: Murashige and Skoog, EDTA: Ethylene diamine tetra acetic acid

\section{References}

Coupe, S.A., Palmer, B.G., Lake, J.A., Overy, S.A., Oxborough, K. 2006. Systemic signalling of environmental cues in Arabidopsis leaves. Journal of Experimental Botany. 57: 329-341.

Fila, G., Badeck, F., Meyer, S., Cerovic, Z. and Ghashghaie, J. 2006. Relationships between leaf conductance to $\mathrm{CO}_{2}$ diffusion and photosynthesis in micropropagated grapevine plants, before and after exvitro acclimatization. Journal of Experimental Botany. 57: 2687-2695.

George, E.F., Hall, M.A. and De Klerk, G.J. 2008. Plant propagation by tissue culture. Dordrecht, Netherlands: Springer Verlag.

Hazarika, B.N., 2003a. Acclimatization of tissue cultured plants. Current Science. 85: 1705-1712.

Hazarika, B.N., 2003b. Morphogenetic response of Citrus in-vitro to varying sucrose level. SAARC Journal of Agriculture. 1: 111-116.

Hazarika, B.N., 2006. Morpho-physiological disorders in in-vitro culture of plants. Scientia Horticulturae. 108:105-120.

Hazarika, B.N., Parthasarathy, V.A. and Nagaraju, V. 2004. Influence of in-vitro preconditioning of Citrus sp. microshoots with sucrose on their exvitro establishment. Indian Journal of 
Horticulture. 61: 29-31.

Heringer, A.S., Vale, E.M., Barroso, T., Santa-Catarina, C. and Silveira, V. 2013. Polyethylene glycol effects on somatic embryogenesis of papaya hybrid UENF/CALIMAN 01 seeds. Theoretical and Experimental Plant Physiology. 25(2): 116-124,

Kabir, A. H., Bari, M.A., Huda, A, K. M., Rezvy, M.A. And Mahfuz, I. 2007. Effect of growth regulators and carbon sources on axillary shoot proliferation from shoot- tip explants and successful transplantation of papaya (Carica papaya L.) Biotechnology. 6(2): 268272.

Muller, B., Pantin, F., Génard, M., Turc, O., and Freixes, S. 2011. Water deficits uncouple growth from photosynthesis, increase $\mathrm{C}$ content, and modify the relationships between $\mathrm{C}$ and growth in sink organs. Journal of Experimental Botany. 62:1715-1729.

Murashige, T., and Skoog F. 1962. A revised medium for rapid growth and bio assays with tobacco tissue cultures. Physiol Plantarum. 15: 473-497.

Panse, V. G., and Sukhatme, P.V. 1967. Statistical methods for agricultural workers. Indian Council of Agricultural Research, New Delhi, India.

Patel, J. R., Patel, R. M. and Patel, S. R. 2013. Factors affecting in-vitro establishment and growth of papaya (Carica papaya L.) var. Red Lady. Agres - An International E-Journal. 2(3): 332-341.

Subenthiran, S., Choon, T.C., Cheong, K.C., Thayan, R., Teck, M.B. and Muniandy, P.K. 2013. Carica papaya leaves juice significantly accelerates the rate of increase in platelet count among patients with dengue fever and dengue haemorrhagic fever. Evid Based Complement Alternat Med 2013.

Tetsushi, H., Sadao, K., Masahiko, Y. and Hiroshi, F. 2008. Mass- production of papaya (Carica papaya L.) saplings using shoot - tip culture for commercial use. South Pacific Studies. 28(2): 8795. 2008.

\section{How to cite this article:}

Neeharika Kanth, Anil K. Singh and Syamal, M.M. 2017. Effect of Sucrose Concentration on Shoot Proliferation of Papaya (Carica papaya L.). Int.J.Curr.Microbiol.App.Sci. 6(10): 16381642. doi: https://doi.org/10.20546/ijcmas.2017.610.197 